University of Texas Rio Grande Valley

ScholarWorks @ UTRGV

$7-2018$

\title{
"The Most Turbulent and Most Traumatic Years in Recent Mexican-American History": Police Violence and the Civil Rights Struggle in 1970s Texas
}

Brent M. S. Campney

The University of Texas Rio Grande Valley, brent.campney@utrgv.edu

Follow this and additional works at: https://scholarworks.utrgv.edu/hist_fac

Part of the Latin American History Commons, Political History Commons, and the Social History Commons

\section{Recommended Citation}

Campney, Brent M. S. "'The Most Turbulent and Most Traumatic Years in Recent Mexican-American History": Police Violence and the Civil Rights Struggle in 1970s Texas." Southwestern Historical Quarterly 122, no. 1 (2018): 33-57. doi:10.1353/swh.2018.0050.

This Article is brought to you for free and open access by the College of Liberal Arts at ScholarWorks @ UTRGV. It has been accepted for inclusion in History Faculty Publications and Presentations by an authorized administrator of ScholarWorks @ UTRGV. For more information, please contact justin.white@utrgv.edu, william.flores01@utrgv.edu. 


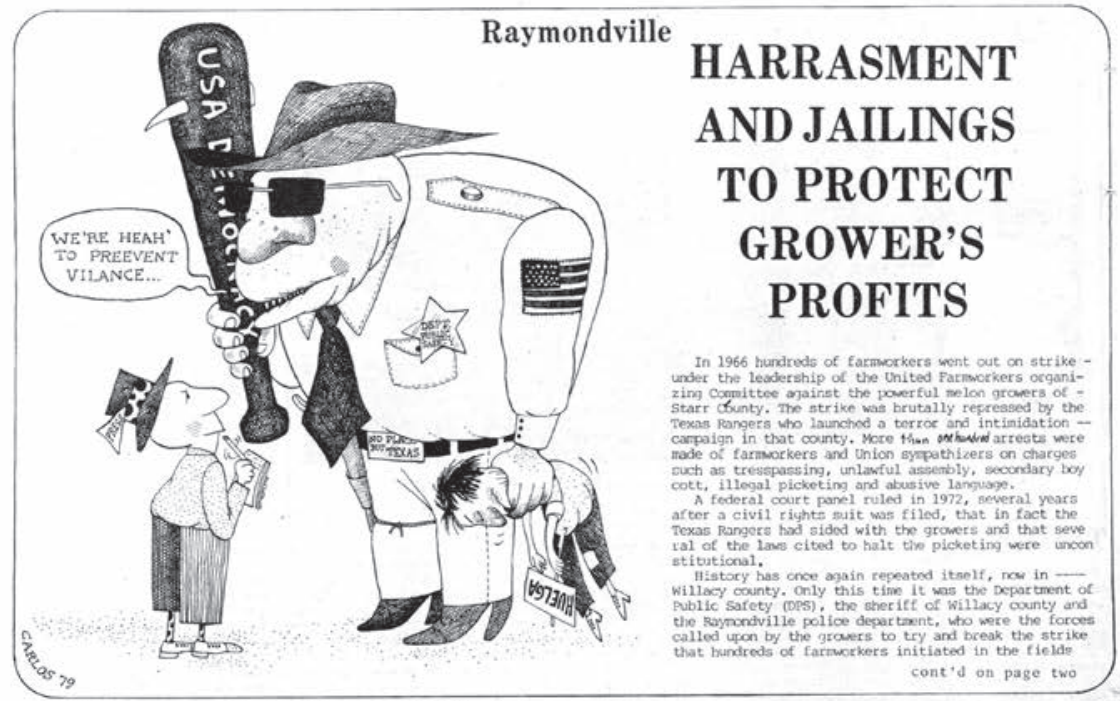

FORREST GREEN STRIKES AGAIN!

H.B. 227 SENT TO A ELGOHAIMIL Official voice of the Texas Farm Workers' Union SUB-COMMITTEE

Forrest Green has sent H.B.227 to a sub-comittoe for "furtherstuci $y^{2}$, af ter having 1 listened to
testivony from Farnorkers, unice testinony fron Fariworkers, union frce religious and civic organiz ations, on the 25th of Apri1. During the hearings on 11.B.227. only two persons-one from the Texas Iarm Bureau and one from the citrus Producers Aesociation - of the Rio Grande Valley-epoke Exch one of the rest of the poor ple talked of the necessity of -
il.3.227 being sent to the house

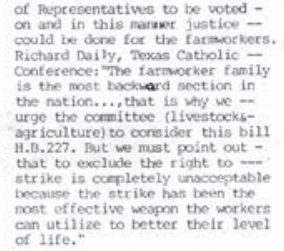

\section{LAWYERS NEEDED URGENTLY!}

More than 20 members and organizers of the Texas Farn Workers Union will be on trial the 16 th of May in Raymondvilie for various charges, Severai of thes, Juat
nita Valdez, Juanita Adame, and Jesus Moya have up to nita daldez, Juanita Adame, and Jesus Moya have up to
three different charges and could be put in jail at any minute. Others being charged are Marcial Silva, Roy Fernandez, Guillermo Daniel Glenn, Ricardo Monje, Gilberto Cantu, Ricardo Olvera, and others. Ernesto Flores of Weslaco, Ruben Sandoval of San Antonio, and Armando lo. the pouston are handiling sone of the cases. Some of sent then. We need the help from lawyers who would help these farmworkers and also help with the defense of the The Also to defend the vorkers against the courts and Contact: Armando lope

c/o Conite de Defensa de1 TFW 3935 Westheiner, 202
Houston, TX 77027

Tele: (713) $965-9240$

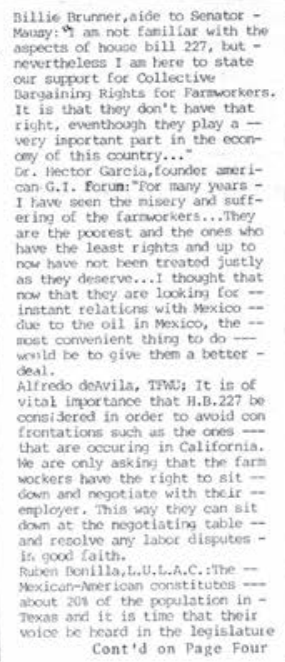

P. O, Box 876, San Juan, Texas 78589 DONATION $15 \mathrm{e}$

The cartoon in the May 5, 1979, edition of El Cuhamil, the paper of the Texas Farm Workers' Union, perfectly encapsulates the fear among many Mexican Americans of police officers. Here, a giant Anglo lawman brandishes a spiked club that reads "USA Democracy" and holds in his other hand a small, strangled Mexican American striker. Portrayed as the very epitome of an uneducated bigot, the officer tells an apparently uncurious journalist that "We're Heah' to Preevent Vilance.'” His belt buckle reads, "No Place But Texas." Chicano Collection, Library Archives and Special Collections, the University of Texas Rio Grande Valley. 


\title{
"The Most Turbulent and Most Traumatic Years in Recent Mexican-American History": Police Violence and the Civil Rights Struggle in I97os Texas
}

\author{
By Brent M. S. Campney*
}

$66\left[\begin{array}{l}\text { here is] an old West Texas ethnic joke that Lubbock State } \\ \text { Rep. Froy Salinas remembers well from his childhood," the } \\ \text { Dallas Morning News reported in one of many columns on }\end{array}\right.$ police violence against Mexican Americans in the Lone Star State in the 1970s. In repeating Salinas's “joke," the Morning News used an ellipsis to signal the transition from the setup to the three-word punchline: "Texas Rangers all have Mexican blood . . . on their boots." Asked for his view, civil rights activist Dr. Héctor P. García asserted that police violence was a central means by which the state and its Anglo majority subordinated that large and growing minority group. "Anytime a policeman's gun discharges in Texas, it goes straight through a Mexican-American's head or stomach," he lamented. "That's a violation of the laws of physics, trajec-

\footnotetext{
*Brent M. S. Campney is associate professor of history at the University of Texas Rio Grande Valley and the author of This Is Not Dixie: Racist Violence in Kansas, I 86I-I927 (Urbana: University of Illinois Press, 2015). He thanks George T. Díaz, Jamie M. Starling, Bill Carrigan, Clive Webb, Sonia Hernández, Trinidad Gonzales, Ryan R. Schumacher, Walter Buenger, and Mike Campbell for their support and contributions to this study. He would also like to thank the excellent staff of the Special Collections and Archives at the University of Texas Rio Grande Valley for their expertise and assistance. The author dedicates this work to the students of the University of Texas Rio Grande Valley.

${ }^{1}$ Reflecting common usage, this piece employs the term "Anglo" where many historians would use the term "white." This usage reflects the fact that, under the 1848 Treaty of Guadalupe Hidalgo which concluded the U.S.-Mexico War, the government of the United States granted citizenship to the Mexicans living in the seized areas. Because naturalization at that time demanded whiteness as a prerequisite, the grant of citizenship effectively conferred white racial status upon those Mexicans. For a discussion of this language, see "Note on Terminology," at the outset of Timothy Paul Bowman, Blood Oranges: Colonialism and Agriculture in the South Texas Borderlands (College Station: Texas A\&M University Press, 2016).
} 
tory and gravity." With their focus on police violence, Salinas and García brought attention to a major issue confronting Mexican Americans in Texas in the 1970 .

The 197 os were marked by numerous high-profile killings of Mexican Americans in Texas by Anglo police officers, especially in the years 1977 and 1978. The killings occurred throughout the state, in large cities like Dallas and Houston and in small towns like Sierra Blanca and Plainview. Although these killings may not have represented an actual increase in slayings of Mexican Americans by law enforcement-indeed memories of the hundreds and perhaps thousands killed by Texas Rangers in the mid1910s remained strong - they did lead to extensive press coverage. Moreover, Mexican Americans responded to the killings with concerted, bold calls for justice, with politicians and older organizations like the League of United Latin American Citizens (LULAC) working together with younger, more radical Chicana/o activists, including the Brown Berets. Through political action and street protests, they demanded the Anglo majority take notice and forced the federal government to respond. Their efforts, however, did not come without backlash.

Historians have focused considerable attention on the abuse of persons of Mexican descent by the American border patrol in its various incarnations but have insufficiently examined that by local police forces in Texas. Based on extensive coverage found in Anglo and Mexican American newspapers, in the papers of LULAC, and in contemporary magazines, this study begins to remedy this omission by focusing on local-level police violence in the $197 \mathrm{os}$. In the first section it analyzes the routine nature of police violence against Mexican Americans, details a serious outbreak of such violence against them, and assesses the lenient penalties, if any, imposed upon the perpetrators. In the second it explores the strategy and tactics employed by Mexican American activists who challenged police violence, its perpetrators, and their defenders. Finally, it discusses the implications of these findings for the scholarship on the Mexican American civil rights struggle. At the outset, however, it places this phase of their long struggle in its historical context within Texas.

This study builds upon a flurry of scholarship focused on racist (primarily mob) violence against Mexican Americans-indeed, persons of Mexican descent broadly-in the American Southwest since 1848 . Some scholars have examined the history of mob violence, particularly lynching, against persons of Mexican descent from 1848 to 1928 in California, Arizona, New Mexico, and Colorado. ${ }^{3}$ Although these southwestern states

\footnotetext{
${ }^{2}$ All quotes in this paragraph come from Dan Watson, "Police, the Mexican-American and Justice," Dallas Morning News, July 16, 1978. Unless otherwise noted, all newspapers and periodicals used in this study originated in Texas.

${ }^{3}$ For the use of mob violence by Anglos against ethnic Mexicans in the mid-to-late nineteenth and
} 
had their share of such violence, historians William D. Carrigan and Clive Webb concluded that Texas was singular: Anglo Texans "were almost universally regarded as possessing the greatest animosity toward Mexicans." Others have focused on mob and police violence. They have addressed in detail the massacre of ethnic Mexicans in the lower Rio Grande Valley in 1915 by mobs and Texas Rangers. In chronicling this massacre, they have provided an important service: identifying the centrality of police violence in Mexican American history. ${ }^{5}$ Until this essay, however, scholars have not addressed comprehensively racist violence or local police violence against Mexican Americans in the Southwest generally or in Texas particularly in the period since the Great Depression. ${ }^{6}$

Because the federal censuses-in contrast to the lived reality-categorized Mexican Americans most often as simply "white" for decades after their incorporation into the United States following the U.S.-Mexico War in 1848 , scholars have sometimes encountered difficulty in determining their precise number and geographical distribution. ${ }^{7}$ Nevertheless, they have estimated both in broad terms. Cultural geographer Daniel Arreola wrote that "the Hispanic American borderland" stretches across South

early twentieth centuries, see Benjamin Heber Johnson, Revolution in Texas: How a Forgotten Rebellion and its Bloody Suppression turned Mexicans into Americans (New Haven: Yale University Press, 2003); Ken GonzalesDay, Lynching in the West, I850-1935 (Durham, N.C.: Duke University Press, 2006); Stephen J. Leonard, Lynching in Colorado, 1859-1919 (Boulder: University Press of Colorado, 2002); William D. Carrigan and Clive Webb, Forgotten Dead: Mob Violence against Mexicans in the United States, I848-1928 (New York: Oxford University Press, 2013); Manfred Berg, Popular Justice: A History of Lynching in America (Chicago: Ivan R. Dee, 2011 ); Miguel Antonio Levario, Militarizing the Border: When Mexicans Became the Enemy (College Station: Texas A\&M University Press, 2012); and Nicholas Villanueva Jr., The Lynching of Mexicans in the Texas Borderlands (Albuquerque: University of New Mexico Press, 2017). Scholars John Morán González, Trinidad Gonzales, Sonia Hernández, Benjamin Johnson, and Monica Muñoz Martínez have recently called for-and achieved-public commemoration of the killings of 1915 and other acts of racist violence in the U.S.-Mexico borderlands. See https://refusingtoforget.org/ [Accessed Mar. 9, 2017].

${ }^{4}$ Carrigan and Webb, Forgotten Dead, 54 .

${ }^{5}$ Johnson, Revolution in Texas; Trinidad Gonzales, "The Mexican Revolution, Revolución de Texas, and Matanza de 1915," in War along the Border: The Mexican Revolution and Tejano Communities, ed. Arnoldo De León (College Station: Texas A\&M University Press, 2012), 107-133; Richard Ribb, "La Rinchada: Revolution, Revenge, and the Rangers, 1910-1920," in Ibid., 56-106.

${ }^{6}$ For a study of police violence against Mexican Americans and their allies in Mathis, Texas, see Felipe Hinojosa, 'iMedicina Si Muerte No!': Race, Public Health, and the 'Long War on Poverty' in Mathis, Texas, 1948-1971," Western Historical Quarterly 44 (Winter 2013): 437-458. On Mexican American prisoners, see Ethan Blue, Doing Time in the Depression: Everyday Life in Texas and California Prisons (New York: New York University Press, 2012); and Kelly Lytle Hernández, City of Inmates: Conquest, Rebellion, and the Rise of Human Caging in Los Angeles (Chapel Hill: University of North Carolina Press, 2017). On federal policing of ethnic Mexicans, see Kelly Lytle Hernández, Migra! A History of the U.S. Border Patrol (Berkeley: University of California Press, 2010); George T. Díaz, Border Contraband: A History of Smuggling across the Rio Grande (Austin: University of Texas Press, 2015); Levario, Militarizing the Border, John Weber, From South Texas to the Nation: The Exploitation of Mexican Labor in the Twentieth Century (Chapel Hill: University of North Carolina Press, 2015). On the criminal justice system and Mexican Americans in Texas, see F. Arturo Rosales, ;Pobre Raza!: Violence, Justice, and Mobilization among México Lindo Immigrants, 190o-1936 (Austin: University of Texas Press, 1999).

${ }^{7}$ For an outstanding discussion of trends in Mexican American population diversity, growth, and change, see Terry G. Jordan, "A Century and a Half of Ethnic Change in Texas, $18_{3} 6-1986$," Southwestern Historical Quarterly 89 (April 1986): 392-401. 
Texas, extends north in a narrow band along the international boundary in West Texas to El Paso, and includes parts of Arizona, California, Colorado, and New Mexico. Citing another scholar, he "called the area a lost homeland, the conquered northern half of the Mexican nation." Within this borderland, he estimated that 83 percent of all Americans of Mexican descent live. He also asserted that the Mexican American population of Texas more than doubled between $195^{\circ}$ and 1990 , that roughly $5^{\circ}$ percent resided in South Texas, and that the half located in that region accounted for some 71 percent of the total population there. ${ }^{8}$

Many Mexican Americans participated in the accelerated urbanization of the state during the post-World War II period. They migrated to and concentrated in regional hubs in West and South Texas, like Odessa, Uvalde, McAllen, and Brownsville and in large metropolitan centers like Houston, Dallas, and San Antonio. In relocating, they were often motivated by the better educational and occupational opportunities available in these cities. Furthermore, they were attracted by the relative safety afforded by their concentration in large numbers in often segregated neighborhoods, a luxury they rarely enjoyed in the rural areas and small towns where Anglos adhered to more crude and overt racism. ${ }^{9}$

In Texas, Mexican Americans have long held suspicions about police officers generally and the Texas Rangers particularly. While they may attribute these misgivings to many wrongs, they could trace them most directly to the massacre of hundreds of ethnic Mexicans-American citizens and Mexican nationals alike-during a wave of repression in the Rio Grande Valley in 1915 . Anglos, who had come to dominate the valley economically and politically (although not demographically) over the previous decade, used raids by groups of ethnic Mexicans upon the property of various Anglo commercial farmers as a pretext for the formation of mobs that attacked and killed anyone who "looked" Mexican, irrespective of their national origin, economic position, or political ideology. ${ }^{10}$ Swept up in the frenzy, the Texas Rangers deputized virtually any Anglo men with guns, granting them immunity and turning them loose; they slaughtered victims across several counties and pushed refugees across the Rio Grande into a Mexico torn by revolution. According to estimates, they murdered from about three hundred to almost five thousand people. ${ }^{11}$

\footnotetext{
${ }^{8}$ Daniel D. Arreola, Tejano South Texas: A Mexican American Cultural Province (Austin: University of Texas Press, 2002), 2, 58 . Historian Brian Behnken observes that there were approximately one hundred thousand Mexican Americans in 1848. Brian D. Behnken, Fighting their Own Battles: Mexican Americans, African Americans, and the Struggle for Civil Rights in Texas (Chapel Hill: University of North Carolina Press, $2011), 24$.

${ }^{9}$ For a discussion of these trends, see David Montejano, Anglos and Mexicans in the Making of Texas, I836-1986 (Austin: University of Texas Press, 1987), 262-287.

${ }^{10}$ Johnson, Revolution in Texas, 116.

${ }^{11}$ Ibid., 3 .
} 
As historians have documented, Mexican Americans have repeatedly challenged their Anglo oppressors in Texas since 1848, often taking up arms. Since the killings of 1915 , they have used many methods. In the 1920 elite Mexican American men formed LULAC to defend Mexican Americans and their rights. In the quarter of a century after World War II, Mexican Americans-men and women alike-launched a well-coordinated campaign for their rights, a struggle centered on legal activism, political pressure, and popular protests. They had greater success at this time because they were able to gain the support of influential businessmen and internationalist politicians determined to win the Cold War and curb the most flagrant expressions of racism at home in order to cultivate the support of so-called Third World nations. ${ }^{12}$

In the mid-to-late 196os Mexican Americans split into two somewhat clearly delineated factions, although their views were obviously more diverse than this blunt analytical division suggests. One faction included their more influential economic and political leaders as well as a goodly number of ordinary Mexican Americans. They pursued a whiteness strategy, arguing that the federal and state governments should grant them these rights because their people were legally white. Accordingly, they advocated change through political channels, using the vote to compel Anglo politicians to address their concerns and applying political pressure to demand from them policies and legislation advantageous to their interests. In short, these Mexican Americans were less interested in obliterating legal racism than in ensuring their inclusion on the right side of it.

Inspired by the African American freedom struggle, the other faction, often younger and poorer, argued that Mexican Americans were not white but brown: a definable racial minority which needed to overthrow the social order, establish a more representative democracy, and pursue self-determination. Reflecting these positions, they adopted the term Chicanoonce a term of racist derision and discrimination-as their own. Historian David Montejano concluded that they "created a social movement that transformed the pejorative lower-class labels of 'Chicano' and 'Chicana' into positive identities. These new identities, based on the notions of 'la raza unida' (the united people) and 'carnalismo' (brotherhood and sisterhood), came to signify solidarity among activists and believers." ${ }^{13}$ Dur-

\footnotetext{
${ }^{12}$ On the role of the Cold War and the concerns of influential politicians and businessmen over the American 'image' in promoting civil rights reform among Anglos, see, for example, Charles M. Payne, I've Got the Light of Freedom: The Organizing Tradition and the Mississippi Freedom Struggle (Berkeley: University of California Press, 1995); Mary L. Dudziak, Cold War Civil Rights: Race and the Image of American Democracy (Princeton, N.J.: Princeton University Press, 200o); Thomas J. Sugrue, Sweet Land of Liberty: The Forgotten Struggle for Civil Rights in the North (New York: Random House, 2008); Cynthia E. Orozco, No Mexicans, Women, or Dogs Allowed: The Rise of the Mexican American Civil Rights Movement (Austin: University of Texas Press, 2009).

${ }^{13}$ David Montejano, Quixote's Soldiers: A Local History of the Chicano Movement, I966-198I (Austin: University of Texas Press, 2010), 2.
} 
ing the 1970 , these factions, which were divided on many issues, worked together in common purpose against what both recognized as an all-out assault on them.

As they had for generations, police officers routinely humiliated and intimidated Mexican Americans and subjected them to physical abuse during arrests or in custody. El Portavoz, a Mexican American paper, lamented police practices in San Antonio in 1971, writing that, "After a while, people stop noticing what policemen do. The fact that they wear a uniform and carry a weapon lends authority to their actions." ${ }^{.14}$ A West Texas sheriff clubbed supposedly unruly prisoners with "a homemade nightstick—actually a sawed-off pool cue." ${ }^{15}$ In Uvalde activists declared that it "is an established tradition" that the "police are given open reign to harass and intimidate and openly assault Mexican-American citizens." ${ }^{16}$ In Mathis, Mexican Americans suffered what an observer in 1971 described as "generations of brutality at the hands of Gringo police."17

Against this backdrop of humiliation, intimidation, and violence, officers killed Mexican Americans, usually young men or youths, in egregious and sometimes high-profile acts. In 1974 an activist in Austin reported that "five chicanos in the predominantly black and Mexican-American district have been killed by police in the last four years." ${ }^{18}$ In a notorious act, Officer Darrell Cain in Dallas shot and killed twelve-year-old Santos Rodríguez in 1973 while he was handcuffed in a patrol car alongside his thirteen-year-old brother, David. In an effort to extract a confession for robbery, Cain "apparently tried to scare Santos into talking by playing Russian roulette with his .357 magnum," noted a reporter. "He (Cain) rolled the chamber around, and then he opened it and there were two or three bullets in it." The officer snapped the chamber shut and pulled the trigger, but the gun did not fire. He warned Santos that "this time it has a bullet in it," David recounted. The officer again pulled the trigger and "'the bullet went through my brother's head and blew the other side of his face off." $" 19$

After Deputy Marshal Donald McCall arrested Richard Morales for an alleged property crime in 1975 , Frank Hayes, the chief of police in Castroville, ordered him to take the prisoner to a gravel road a few miles from town, reporters recounted. "Hayes then ordered Morales out of the

\footnotetext{
${ }^{14}$ El Portavoz (San Antonio) 1971, reprinted in Montejano, Quixote's Soldiers, 131.

15 "Jailhouse Rock," Texas Monthly, August 1977, 7 o.

16 “\$9oo,ooo Damage Suit Alleges Police Brutality in Uvalde," Eagle (Bryan, Tex.), May 16, 1978.

${ }^{17}$ Bill Moyers, Listening to America: A Traveler Rediscovers His Country (New York: Harper's Magazine Press, 1971), 227.

18 "Austin Police Force under Race Pressure," Valley Morning Star (Harlingen, Tex.), Oct. 1 2, 1974.

19 "Murder Trial Begins Today for Dallas Police Officer," El Paso Herald-Post, Nov. 12, 1973. Several years earlier, Officer Cain had shot a black man, killing him; consequently, blacks in Dallas were likewise outraged by the killing of Rodríguez. See Behnken, Fighting Their Own Battles, 174.
} 
deputy's car and that his handcuffs be removed." McCall later testified that Hayes produced a shotgun from his vehicle and "ordered McCall to leave." At some point in the prisoner exchange between McCall and the chief of police, Hayes declared that "I've killed me one Mexican, and I'm fixin' to kill me another." "As the deputy drove away, Hayes shot Morales. ${ }^{21}$ Concerned that his story of self-defense would not pass muster, Hayes drove the corpse across the state. The Dallas Morning News reported that it "was discovered two days later buried on Hayes' brother-in-law's farm in Carthage, 400 miles from Castroville." ${ }^{2} 2$ The victim's brother Ben told a reporter that Richard "knew he was going to get killed one of these days. They [the police] used to pick him up all the time.'"23

In most instances officers could be certain that they would face no charges because coroners' juries offered wide latitude to their claims of self-defense. When prosecuted, policemen could be confident of acquittals or, in the case of convictions, lenient sentences. Even in the egregious Russian roulette killing of Santos Rodríguez, the Dallas officers enjoyed lenience. The shooter, Darrell Cain, "was convicted of murder with malice and is serving the minimum 5 -year sentence," summarized the Morning News. Ultimately, he served half of his sentence. Cain's partner "was not prosecuted, but has left the police department." ${ }^{4}$

As the foregoing suggests, officers in Texas killed Mexican Americans casually in the early-to-mid 1970s, much as they had throughout the twentieth century. However, Mexican American activists and the state press reported that officers increased the number of such killings perceptibly in 1977-78, when they killed eighteen Mexican Americans across the state. Whether officers actually did increase the number of killings over these two years is unclear from existing data; certainly, if officers in Austin killed five Mexican Americans in Austin alone between 1970 and 1974, then eighteen incidents across the state over two years may not actually have been a particularly high number. However, because Mexican American activists publicized the incidents vigorously in these years and because the state press covered their protests, contemporaries-particularly Mexican Americans themselves-experienced $1977-78$ as a period when highly suspicious killings-by-police were surging in the Lone Star State.

\footnotetext{
20 “Dead Man [Found?] in Panola County," Longview Daily News, Sept. 17, 1975.

${ }^{21}$ David J. Krajicek, "The Death of a Mexican-American at the Hands of a Texas Marshall in 1975 Triggered Civil Rights Action by Justice Department," New York Daily News, July 18, 2015.

22 "Federal Grand Jury to Probe Texas Death," Dallas Morning News, Feb. 12, 1977.

23 "Body is Dug up in East Texas," San Antonio Express, Sept. 17, 1975.

${ }^{24}$ Don Mason and Don Fisher, "3oo Rally to Protest Slayings," Dallas Morning News, July 23, 1978. On Cain serving only half his sentence, see "Retired Officer Remembers the Night Santos Rodriguez was Killed,” CBS/DFW, July 27, 2013, http://dfw.cbslocal.com/2013/o7/27/retired-officer-remembers-thenight-santos-rodriguez-was-killed/ [Accessed Jan. 13, 2017 ].
} 
The sensational reports of the killings came fast and furious over the two-year period under investigation. In February 1977 guards at the Bexar County Jail in San Antonio beat to death Juan Zepeda. According to eye witnesses, "Zepeda was thrown by jail guards and he fell 'like a sack of salt.'" ${ }^{25}$ Although the officers initially suggested that Zepeda received his injuries in a bar fight or during his arrest, the coroner disagreed. "The amount of internal bleeding indicated death came almost immediately after he was struck," he explained. "Had he been injured at the time of arrest, he probably would have died before he got to jail."

In another large Texas city, José (Joe) Campos Torres drowned on May 6 "after he allegedly was beaten by police and then shoved into the Buffalo Bayou in downtown Houston." ${ }^{27}$ After arresting (and beating) Torres for intoxication, the officers conveyed him to jail where officials refused to admit him because of his injuries and instructed the officers to take him to a hospital. Instead, they took him to the Buffalo Bayou. After again beating him, they pushed Torres off an embankment. One of the officers joked to another that "you've always wanted to throw a wetback in the bayou. This would be a good time." ${ }^{28}$ A passerby discovered the body floating in the water two days later. ${ }^{29}$

That same month police targeted Juan Zuñiga, "allegedly beaten to death in the Hudspeth County jail." ${ }^{30}$ A reporter for the El Paso HeraldPost visited the scene and found an insular Anglo population circling the proverbial wagons. "Sierra Blanca is a small, sun-baked town off Interstate 10 about 100 miles east of El Paso. The people here don't want to talk about what happened, at least not publicly." The sheriff, the Herald-Post claimed, "is a good man, a fine Christian," but, having "to police the third largest county in Texas [in geographic terms] with a five-person staff, [he] 'may get a little tough now and then.'” A waitress conceded that many townspeople were "terribly concerned. Something happened, something bad. "' ${ }^{31}$ Regrettably, the reporter could make no headway with locals who regarded him as an unwelcome and potentially threatening intruder. "These lawmen are a tight-knit group, and resentful of newsmen," he concluded. "They won't talk about it to an outsider." 2

25 “Guards Probed in Jail Deaths," Dallas Morning News, Mar. 6, 1979.

26 "Examiner Thinks Blows Followed Arrest," San Antonio Express, Feb. 24, 1977.

27 "Justice Probe Reported in Four Minority Cases," Dallas Morning News, Sept. 4, 1977.

28 “Torres Trial Darkens Houston Police Reputation," Abilene Reporter-News, Sept. $23,1977$.

29 “Officer Says Torres Jumped in to Escape," Del Rio News Herald, Sept. 27, 1977.

30 "Justice Probe Reported in Four Minority Cases," Dallas Morning News, Sept. 24, 1977.

${ }^{31}$ Bill Thompson, "Jury Starts Probe of Prisoner Death in Sierra Blanca," El Paso Herald-Post, May 27 , 1977 .

${ }^{32}$ Bill Thompson, "Jury Starts Investigation of Hudspeth County Death," El Paso Herald-Post, May 27 , 1977 . 
In December officers in Big Spring shot a nineteen-year-old Mexican American suspected of purse snatching. Juan Galavez fled the scene in a car but "was pursued by three Big Spring police units. One of the police cars rammed the vehicle." According to police accounts, Galavez emerged from the vehicle and "was shot in the temple as he reached into his pocket. Police found a knife on the wounded Galavez." 33 Three months later a grand jury refused to indict Officer Leroy Spires. "'The grand jury did not find sufficient evidence to return any indictments,' District Attorney Rick Hamby said." Mexican Americans vigorously disputed the use of lethal force, transforming this incident into "a key point in a statewide campaign ... to point out police brutality against minorities." ${ }^{44}$ Unfortunately, aside from very successfully publicizing the killings, they could do little to curb the violence.

In January 1978 officers in the Ector County Jail in Odessa wrestled with and killed Larry Lozano who, they claimed, was having a psychotic episode. Sheriff Elton Faught blamed the victim. "His death was the most horrible accident," he told the Odessa American. "It is the kind of injury that could happen to a football player, someone running into a clothes line, or a traffic accident." 35 Initially, the medical examiner determined that Lozano's body was covered in wounds and that the "cause of death was homicide from blunt trauma caused by kicking and beating and the use of sharp instruments." Before long, he changed his tune. He "now thinks death was caused by injuries to Lozano's larynx. The 92 bruises and wounds on the body were 'life-threatening' injuries, but were not fatal injuries." He added that "it was not for him to say whether the homicide was intentional or accidental, but conceded that it could be either." ${ }^{36}$

Also in January, a deputy in Moon City, near El Paso, shot and killed seventeen-year-old Socorro High School student Danny Vásquez. Some observers claimed that the youth grabbed the gun, provoking an accidental discharge; others claimed that Vásquez slapped the gun aside and drew back at which point the officer fired. ${ }^{37}$ In August police killed Paul Martínez in a town in the Panhandle. Immediately thereafter, LULAC "sent telegrams to federal and state officials asking them to observe the investigation in Perryton into the police shooting of a Mexican-American." A Mexican American leader observed that in the case of Martínez, "it took a shotgun and a .357 magnum to complete the killing" but in other locales it required only a revolver. ${ }^{38}$ Over the balance of the year, officers killed

\footnotetext{
33 "Big Spring Police Kill 19-Year-Old," Del Rio News Herald, Dec. 9, 1977.

34 "Officer Indictment Refused," Longview Daily News, Mar. 31, 1978.

${ }^{35}$ Matt Conklin, "Larry Lozano: Aftermath of Death," Odessa American, Apr. 16, 1978.

${ }^{36}$ Matt Conklin, "Pathologist Terms Lozano Death Homicide," Odessa American, Apr. 12, 1978.

37 "Damage Suit Filed," Dallas Morning News, Apr. 1, 1978.

38 "Federal, State Officials asked to Monitor Shooting Inquiry," Dallas Morning News, Aug. 3, 1978.
} 
several more Mexican Americans. "The murders continue," lamented an activist. "Human rights in Texas continue to be denied by law enforcement agents.' "'39

Although the preceding incidents represent some of the worst abuses of the police in Texas, the head of the West Texas branch of the Brown Berets, a Mexican American civil rights group advocating armed selfdefense, underscored just how common and underreported these incidents were. "Right now, there are six [suspicious] deaths in Texas,", observed Gilbert Herrera in July. "'In the past year, we've had 17 deaths, about two a month, and the investigations always come out the same, accidental."'40 The Dallas Morning News provided a lower estimate of victims but recognized the gravity of the issue. The Mexican American movement against police violence, it claimed, was "fed by both documented incidents and unfounded rumors." ${ }^{41}$

As indicated, officers had wide latitude to claim self-defense when they killed Mexican Americans, even when the facts did not validate their accounts. They exercised that prerogative and coroners' juries honored it with acquittals. When prosecuted and convicted, they received lenient sentences. In the drowning of Torres, a jury found two of the Houston officers guilty not of the initial murder charge but of the less serious charge of criminally negligent homicide. The "all-white jury of seven women and five men deliberated ${ }_{15}$ hours before returning the verdict against Terry Deason, 27, and Stephen Orlando, 21 ," an observer reported. "It was one of the lightest the jury could have handed down." ${ }^{42}$ In fact, it only gave the pair "probated sentences and fines." ${ }^{43}$ Subsequently, the two officers faced federal charges that resulted in a ten-year suspended sentence for a civil rights violation and a year in jail for the assault. State Representative Ben Reyes of Houston declared that "this was the biggest miscarriage of justice I have ever witnessed. Our community is saddened. It only proves there is a dual system of justice." "'44

Many officers surely investigated these killings fairly but some just as surely tipped the evidentiary scales in favor of their fellow officers. In 1977, for example, an officer in Garden City shot and killed Tiburcio Griego Santome, a Mexican national. Local officials reacted in a way that underscored the gap in understanding between Anglos and Mexican

\footnotetext{
${ }^{39}$ Larry Jolidon, "No Indictment in Slaying of Chicano," LULAC Word (Corpus Christi, Tex.), August 1978, in Chicano Serials, Chicano Collection (Library Archives and Special Collections, the University of Texas Rio Grande Valley), cited hereafter as Chicano Collection, UTRGV.

${ }^{40}$ Dan Watson, "Police, the Mexican-American and Justice," Dallas Morning News, July 16, 1978.

${ }^{41}$ Ibid.

${ }^{42}$ Rob Wood, "Houston Officers Convicted," Abilene Reporter-News, Oct. 7, 1977.

43 "Parents of Torres Arrested in Houston," Valley Morning Sun (Harlingen, Tex.), Oct. 11, 1977.

${ }^{44}$ Wood, "Houston Officers Convicted," Abilene Reporter-News, Oct. 7, 1977.
} 
Americans who in this and one other case took up the cause of immigrant Mexicans as their own. The officials asked the Texas Rangers to conduct an investigation because in their view they represented the gold standard in state law enforcement. One explained that "the Rangers were called in on the case to add credibility to the findings. 'They're about as independent a group as you can get,' he said." ${ }^{45}$ Presumably, Mexican Americans did not embrace that rationale. As the New York Times declared, "Texas Rangers . . . are almost universally feared among Mexican-Americans." 46

Although most of those killed in 1977-78 were Mexican American, two were Mexican. One was Santome; the other was Jesús Martínez Gallegos, killed by Officer Keith Reed in Waco in 1978. The victim, "a 34-yearold Mexican national in this country illegally, was shot while fleeing from Reed. He had struggled with Reed before he broke away. Reed said he fired two warning shots and ordered Gallegos to stop." ${ }^{47}$ A reporter indicated that after "18 hours of deliberation the grand jury said Monday night it found no evidence to support prosecution of Reed." In an apparent reference to the breech in attitudes between Mexican Americans and Anglos, State District Judge Carl Anderson "told the jury 'there are people who won't agree with you but the vast majority will.' "48 Mexican Americans saw the verdict differently, vowing to raise the issue with federal authorities, seeing it as another instance of police brutality. A leader mourned that an "epidemic" was " under way-a systematic taking of lives by law enforcement officers." "49

Despite the fact that most of the victims were Mexican American, they almost certainly died in part because of an emotional national debate over the issue of amnesty for undocumented Mexican laborers, a debate that provoked an often violent backlash against these exploited workers-and anyone else who "looked" Mexican-in the late 1970s. Across the Southwest vigilantes targeted those they deemed "Mexican." In Douglas, Arizona, they kidnapped three undocumented workers and mauled them nearly to death. Describing the torture to which they subjected the victims, a civil rights report stated that "two of the [victims] had been peppered with birdshot from shotgun blasts and the third had been 'hung by the neck but managed to escape strangulation.'" The Arizona vigilantes received an acquittal by a "'racist, all-white jury." The vigilantes were so active that in 1978 the Civil Rights Division of the Justice Department was "investigating 'about 9o' cases in Texas alone." An activist drew a link

\footnotetext{
45 "Mexican Prisoner Shot in Squad Car," Del Rio News Herald, Nov. 8, 1977.

${ }^{46}$ Martin Waldron, "Chicano March is Quiet in a Tense Texas Town," New York Times, Mar. 14, 1971.

47 "Policeman No-Billed in Death of Mexican," Del Rio News Herald, Sept. 26, 1978.

48 "Officer No-Billed in Fatal Shooting of Mexican Native," Paris News, Sept. 27, 1978.

49 "U.S. Probe Urged in Killing," LULAC Word (Corpus Christi, Tex.), October 1978, Chicano Collection, UTRGV.
} 
between the killings and the public debate over immigration: "There have been reported beatings and killings of undocumented workers in the United States as a result of the prejudice and discrimination enhanced by mass publicity of this issue." ${ }^{50}$

Many Anglos did not differentiate between Mexican Americans and Mexicans because they viewed both as inherently foreign, unassimilable, and effectively indistinguishable: a Mexican was anyone who "looked" Mexican to them, whether a U.S. citizen or not. As a result, they vented their anger over "illegals" towards any person of Mexican descent (and, one suspects, against other Hispanics). When President Jimmy Carter announced a plan in 1977 to grant amnesty to "millions of illegal aliens," a LULAC official worried about these perceptions and their consequences. "He was concerned that there may be a 'backlash effect' against MexicanAmericans if the administration proposals are adopted." He substantiated his concern with a comparison to the backlash "'against blacks in the south during the push for civil rights [in the $195^{\circ}$ os and 196os]."'

A. Miguel Romo, former director of the National Congress of Hispanic American Citizens, drew a similar connection in testimony before Congress, accusing the press of stoking the hatred upon which vigilantes acted. "The 'mass publicity' given to the illegal alien problem has spawned incidents of torture and murder," he remarked. "I can't help but believe that the visibility of this issue may have something to do with the mass rage of police brutality in Texas which has resulted to date in the deaths of more than ten Mexican-Americans while in police custody." ${ }^{52}$ The LULAC Word corroborated this tendency. "In 1978 , the mass hysteria and emotionalism against the Mexican alien affected adversely the rights and privileges of our own Mexican-American citizens. ${ }^{153}$

Their concerns over media coverage of "illegal aliens" were certainly justified. In 1978, the Paris News ran a flagrantly racist story on a "New Order" of Mexican immigrants who came to the U.S. to "rape, rob, mug, burgle, pimp, whore, shoplift and vandalize." The author, journalist Tom Tiede, fondly recalled what he thought of as the good Mexican immigrant of previous days who toiled hard for low wages in order to feed his family. The "invasion phenomenon," he mourned, was changing dramatically as a predator class swarmed into the country. "The 'wetbacks' of old are today being joined by a new and thoroughly reprehensible order," and the new

\footnotetext{
50 "Alien Publicity Blamed for Brutality," Paris News, May 17, 1978.

${ }^{51}$ Wade Roberts, "Carter's Illegal Alien Amnesty Could Alter U.S. Politics," LULAC Word (Corpus Christi, Tex.), September 1977, Chicano Collection, UTRGV.

52 "Alien Publicity Blamed for Brutality," Paris News, May 17, 1978.

53 "Director's Insight," LULAC Word (Corpus Christi, Tex.), December 1978, Chicano Collection, UTRGV.
} 
immigrants were looking for plunder, not labor. At the end of the lengthy piece, Tiede returned to mourn again the lost "old" style immigrant-and the disappearance of lynching which had once dealt with these outlaws. "Jose with the sombrero? It's a quaint but dated picture. The truth is many Mexicans are now using America, in the same way Americans once used Mexico, to raise hell and quick money. The difference is that border plunderers are not hung anymore; at best, they are merely sent home to rest up until the next time." ${ }^{54}$ Considered together, the evidence suggests that the police killings in 1977-78-whether they constituted a spike in such killings or not-were driven in part by a largely undifferentiated hatred aimed at anyone who appeared to be an "illegal."

Officers tended to target Mexican American men but placed an unrelenting burden on their mothers, wives, sisters, and daughters as well. Five years after the killing of Santos Rodríguez, his mother was inconsolable during a protest march and memorial. "Mrs. Bessie Rodriguez, Santos's mother . . . left in tears after reporters found her sitting in the crowd during the rally," noted the Dallas Morning News. "The way I feel right now, I might say something I shouldn't,' she said. 'I talked to my attorney in Washington. He said he didn't have no more hope. He called me last night and said the case is closed. I'm not going to give up hope. I want justice, and justice wasn't done." "555 The mother of José Campos Torres, the young man who had been killed by officers in Houston in 1977, expressed similar anguish: “They killed my son as if he was nobody, as if he was an animal." However, she speculated, if her son had killed an officer, he would likely be "on death row." 56

Mexican Americans responded in various ways. In some instances they organized protests. After the inquest in Odessa found the death of Larry Lozano in the Ector County Jail to be accidental, two hundred activists collected at the courthouse and called the "verdict a 'charade' and the inquest a 'circus," explained the Odessa American. Carrying signs and chanting slogans, the group marched for hours. Inside the courthouse Sheriff Faught liked the verdict. "I am relieved at the outcome, and feel my department has been cleared of any wrong-doing in the Lozano death. The pressure is off and I hope that it is over." On the same day as this protest in Odessa, the American noted another example of local discrimination, writing that "Ector County has been put on notice by the federal gov-

\footnotetext{
${ }^{54}$ Tom Tiede, "New Order of Illegal Aliens Crossing Rio Grande Today," Paris News, Dec. 13, 1978.

${ }^{55}$ Mason and Fisher, “3oo Rally to Protest Slayings," Dallas Morning News, July 23, 1978.

${ }^{56}$ Wood, "Houston Officers Convicted" in Abilene Reporter-News, Oct. 7, 1977. Recent lynching scholarship likewise focuses on the often inter-generational impact of racist violence on black families, including parents, siblings, and children. See for example, Villanueva, Lynching of Mexicans in the Texas Borderlands; Donald C. Mathews, At the Altar of Lynching: Burning Sam Hose in the American South (New York: Cambridge University Press, 2018).
} 
ernment that it faces the possible cutoff of revenue sharing funds unless it changes its hiring procedures for blacks. ${ }^{.57}$

In 1978 young Mexican Americans clashed with Houston police in riot gear "at a housing project in the near Northside Mexican-American barrio ... after youths pelted a store with rocks and bottles late Monday on the second day of disturbances that have resulted in at least 16 injuries and over 30 arrests." In addition to taunting police, the protestors vandalized businesses and hurled firebombs that resulted in property damage. Specifically, they protested the police violence and the lenient punishment received by those responsible for the Torres drowning. "Feeling has run high in the Mexican-American community since the death last year of a 23-year-old Mexican-American while in police custody," a reporter noted. "Sunday also marked the first anniversary of the day the body of Joe Campos Torres showed up in a bayou that runs through downtown Houston." Even though the jury convicted some of the officers involved, "a federal judge assessed [three of] them [just] five-year suspended sentences on the felony conviction. ${ }^{" 58}$ Mexican American protesters chanted: "Joe Torres dead, cops go free, that's what the rich call democracy." ${ }^{59}$ With their uprising, however, they did effect change, prompting the Houston police department to undergo restructuring. ${ }^{60}$

In June of 1978 the Brown Berets threatened retribution against officials if police violence did not cease. Juan Pérez, a spokesman for the Dallas Brown Berets, said that a riot was possible in that city, like the one that had wracked Houston a few months earlier. "Anything the people in the community decide to do, we will support,' Perez [sic] said. 'We won't try to prevent it." In Lubbock "another Brown Beret said Mexican-Americans will become more militant if another Mexican-American is killed." Gilbert Herrera advised reporters that the offending officer in such a case "would be hunted down." ${ }^{61}$ In response to the succession of killings in the summer of 1978, Mexican Americans coordinated mass protests. On June 3, for example, the News reported that they had "demonstrated across the state against police brutality Friday." ${ }^{2}$

\footnotetext{
${ }^{57}$ All quotations from Odessa American, Apr. 13, 1978. See articles by Cynthia Biggers ("Demonstrators Protest Lozano Inquest Ruling”), Shelley Barker ("Sheriff 'Relieved' at Jury's Verdict”), and Bob Luckett ("County Must Alter Hiring Practices").

${ }^{58}$ Susan Linnee, "Police Stand Guard at Riot-Torn Mexican-American Barrio," Eagle (Bryan, Tex.), May 9, 1978 .

${ }^{59}$ Jack Williams, "Moody Park Part 2 - The Riot," May 7, 2008, Houston Public Media, http:// www.houstonpublicmedia.org/articles/news/2008/05/07/10303/moody-park-part-2-the-riot/ [Accessed Dec. 29, 2016].

${ }^{60}$ Marialuisa Rincon, “40 Years Ago Police Killed Joe Campos Torres Sparking Massive Moody Park Riots," Houston Chronicle, May 10, 2017.

${ }^{61}$ Lloyd Grove, "Police Brutality Not Seen as Problem," Dallas Morning News, June 3, 1978.

${ }^{62}$ Ibid.
} 
As the Lubbock Brown Beret had warned, the group did take more "militant" action after the death of another Mexican American, Adán Hernández, who was found hanged in his jail cell in Houston on October 2, 1978, a sequel to the Torres drowning. On November 18, a few weeks after the suspicious hanging, Berets at a Houston park "fired an 18-gun salute for 18 Mexican-Americans they say were killed by police in the state this year." A squadron of officers arrested the Berets, who put up no resistance. "Following the salute, Brown Beret leader Ernest Fraga said, 'We want people to imagine that the sounds (of the salute) are those of the police killing a chicano." 63

Amid the bloodshed of 1977-78 Mexican Americans viewed the issue of police violence as a potent unifier. "From the Mexican-American viewpoint, state grand juries, trial juries and prosecutors are obviously siding with police officers involved with the deaths of Hispanics in Texas," cautioned the Dallas Morning News. "Chicanos are additionally disturbed because most incidents resulting in the deaths of Mexican-Americans in police custody involved arrests on misdemeanor and usually alcoholrelated charges." The paper assessed the implications of their concerns: "In a sense, each death represents a potential martyr and rallying point for civil rights causes, whether the killing was actually justifiable or not. And Mexican-American leaders have come to view each death as an injustice and probable cover up." 64

In addition to their protests, Mexican Americans fought through the legal system. After Officer Charles Cypert killed Tim Rosales in Plainview in 1978 and "a Hale County grand jury took no action," the Mexican American community reacted swiftly, bypassing local officials and appealing to state and federal officials for redress. One leader asked Texas Attorney General John Hill to investigate and others asked the Federal Bureau of Investigations (FBI) to open an inquiry. ${ }^{65}$ In short, the Rosales killing "touched off a powder keg of resentment by Hispanic leaders who say there is an epidemic of police brutality against Mexican-Americans." A LULAC leader lamented "the "repetitive nature of such atrocities in the state of Texas." "66

Despite investigations at local, state, and federal levels, Mexican Americans remained frustrated at the lack of positive responses to their pleas.

\footnotetext{
63 “10 Arrested after Brown Beret Rally," Dallas Morning News, Nov. 19, 1978. In the Hernández case officers claimed that the prisoner killed himself. Mexican Americans, understandably suspicious, declared that Hernández had displayed no suicidal behavior prior to his arrest.

${ }^{64}$ Dan Watson, "Nine Incidents Cited by Mexican-Americans," Dallas Morning News, July 16, 1978.

65 "Grand Jury Take No Action," LULAC Word (Corpus Christi, Tex.), July 1978, Chicano Collection, UTRGV. See also, "FBI Investigation Asked in Police Custody Death," in same issue.

66 "Powder Keg Touched Off in Hispanic's Shooting," Longview Daily News, June 27, 1978.
} 
Froy Salinas mused that "Chicanos in general are very unified" and that, differences aside, most "want action today. It's gotten to the point where the people aren't being satisfied by 'investigation type things.'” Increasingly, they recognized the political implications of demographic changes and used them to their advantage. "The realization that more than 1.8 million Hispanics in Texas are of voting age isn't hindering the push," observed the Dallas Morning News. "Nor is the fact that campaign strategists now concede that a candidate can no longer carry all the cities in the eastern and mostly white part of Texas and still depend on winning an elected office." A Mexican American made a similar point. "We're beginning to see some things change. . . For once, the Mexican-Americans in the U.S. are realizing it. It's a sleeping giant, and when it awakes, the whole world is going to tremble. ${ }^{\prime 67}$

Mexican Americans were so successful in applying pressure that in 1978 they helped convince the U.S. attorney general to make a visible shift in the policy regarding police violence. "Griffin Bell's February modification of the Justice Department's position on criminal civil rights cases to stress more prosecutions is an encouraging sign in the eyes of Mexican-American activists," explained the Dallas Morning News a few months later. The protests against police violence were "capturing the full attention of the U.S. Department of Justice and elected officials who are being told almost daily by phone or letter that Mexican-Americans want full civil rights and vigorous state and federal prosecution of law enforcement officers who abuse Mexican-Americans. ${ }^{.68}$

Prominent Mexican Americans, including LULAC leaders, laid the groundwork for Bell's shift by threatening "to withdraw support [from] President Carter unless his administration is more responsive to their needs. They also issued a list of demands to Carter about police practices in general and accused the justice department of being unresponsive." ${ }^{\prime 9}$ In July 1978 Drew S. Days III, a former attorney with the Legal Defense Fund of the National Association for the Advancement of Colored People and now the first black leader of the Civil Rights Division within the Justice Department, announced that he was planning a trip to Texas to meet with activists and politicians, and to discuss the establishment of "a more vigorous criminal civil rights prosecution directed specifically at complaints about brutality against Mexican-Americans." With his announcement Days captured the attention of R. E. Culbertson, the sheriff of Jefferson County and president of the State Sheriff's Association. He called Days's "plans to visit Texas 'strictly political," and said: "I think the president or

\footnotetext{
${ }^{67}$ Watson, "Police, the Mexican-American and Justice," Dallas Morning News, July 16, 1978.

${ }^{68}$ Ibid.

${ }^{69}$ Ibid.
} 
somebody in his office said let's go down there and put on a show because we may be on dangerous ground.'"70

Although he was as pleased with Days's decision as Culbertson was irritated, Héctor P. García too recognized that it was 'strictly political.' He called Days's "announcement a landmark move for civil rights groups which he said have heretofore never received such quick attention from the justice department." He acknowledged that the "justice department's increased interest in civil rights in Texas was a direct result of [President] Carter meeting with Mexican-American leaders June 23 during Carter's visit to Texas. During the meeting with 27 Mexican-American leaders and legislators, Carter was handed a position paper on police brutality." that meeting a state representative from San Antonio reminded Carter that "the people of Texas realize more the importance of the MexicanAmerican vote than perhaps does the president. There are several candidates who lost the recent primary elections who failed to realize the importance of our vote."72

Mexican American activists were pleased with the recent support from the federal government, but García stressed that they were equally determined to get it from the state government-and more than happy to leverage the former to achieve the latter. "We will not stop any investigation (of police brutality) on the state level but we want a concurrent move on the federal level so by the time the feds get to the people [witnesses] they haven't been intimidated or fired. . . . I have no more trust in the Texas system of justice than the Texas educational system. They were set up not to help us. They were set up to injure us." "73 Mexican Americans achieved success in December 1978 when the attorney general of Texas, a Democrat, declared that "Texas needs a federal-style civil rights law that provides long prison terms for policemen and sheriffs' officers who cause the deaths of prisoners." Leaving no doubt as to his intended audience, he declared that "he reached that conclusion after his staff investigated the deaths of 10 Mexican nationals or Mexican-Americans in Texas jails or at the hands of law enforcement officers." 74

Not surprisingly, Mexican Americans in leadership positions had by far the most influence to press the levers of power on behalf of the population

\footnotetext{
${ }^{70}$ Ibid. On Drew S. Days III, see Reg Murphy, Uncommon Sense: The Achievement of Griffin Bell (Atlanta: Longstreet, 1992), 175. Days later became the solicitor general in the U.S. Department of Justice during the first term of President William J. Clinton.

${ }^{71}$ Watson, "Police, the Mexican-American and Justice," Dallas Morning News, July $16,1978$.

${ }^{72}$ Bob Wood, "Carter Promises Texas Hispanics Help," Eagle (Bryan, Tex.), June 24, 1978.

${ }^{73}$ Watson, "Police, the Mexican-American and Justice," Dallas Morning News, July 16, 1978.

74 "Hill Urges Texas Civil Rights Law," Paris News, Dec. 29, 1978, 11 . See also "John Hill Says Texas Laws Grossly Inadequate on Civil Rights," LULAC Word (Corpus Christi, Tex.), November 1977, Chicano Collection, UTRGV.
} 
generally. When Ruben Bonilla, the executive director of LULAC, became frustrated by the killings in 1977 , he could credibly declare his intent to press the Carter Administration for action. "Bonilla said he would travel to Washington later in the day to meet with Justice Department officials to reiterate demands for federal prosecution[s]" of offending lawmen, reported press accounts following the lenient sentencing of the officers who had killed Torres in Houston. Mexican Americans were angry, Bonilla declared, and wanted their anger to be known by the White House. "If the federal government takes no action, we will know that Washington does not give a damn about our interests and we will remember that in the next election.'" He reiterated his remarks with a shot at the president. "We don't want any more double talk. We want a commitment consistent with Carter's talk about human rights." "75

Although leaders like Bonilla enjoyed a level of access to power denied to most Mexican Americans, 'ordinary' people reinforced their efforts. Those who marched in Dallas in July 1978 increased the political pressure on national leaders, carrying signs and chanting, "Down with Carter, down with Bell,' references to the president and Atty. Gen. Griffin Bell.” A Brown Beret predicted that Bell's decision "not to pursue" the 1973 killing of twelve-year-old Santos Rodríguez under federal civil rights charges "will cause Carter to lose the Mexican-American support that helped him carry Texas in $1976 .{ }^{\prime 76}$ At the march in Dallas in 1978 the protestors were trying not only to memorialize the slain youth but to pressure the Carter Administration for civil rights charges against his killer. "Monday is the fifth anniversary of Rodríguez's death, and the date the statute of limitations on civil rights prosecution will expire," explained the Dallas Morning News. ${ }^{77}$

To be fair, the Justice Department had, however tepidly, investigated and prosecuted some killings of Mexican Americans in Texas in the 1970s. In the Morales case, for example, it had initiated an investigation but the U.S. attorney general decided not to pursue it because Texas investigators were already pursuing it and because at that time the federal government deferred to the state once it had opened an investigation. Thereafter, Texas prosecutors did pursue the case and a jury of ten Anglos and one black in distant San Angelo recommended a modest sentence. According to the New York Daily News, "He was sentenced to two to 10 years in prison but was expected to serve as few as 18 months." Charged with aiding her husband in the disposal of Morales's corpse, Dorothy Hayes, "his body-burying wife, convicted of evidence tampering, paid a $\$ 50$ fine and walked free. ${ }^{\prime 8}$

\footnotetext{
${ }^{75}$ Wood, "Houston Officers Convicted," Abilene Reporter-News, Oct. 7, 1977.

${ }^{76}$ Mason and Fisher, "3oo Rally to Protest Slayings," Dallas Morning News, July 23, 1978.

${ }^{77}$ Ibid.

${ }^{78}$ Krajicek, "The Death of a Mexican-American at the Hands of a Texas Marshall in 1975 Triggered Civil Rights Action by Justice Department," New York Daily News, July 18, 2015.
} 
In an initial salvo of good intentions towards Mexican Americans, Attorney General Bell announced in early 1977 that a federal grand jury would investigate the killing of Richard Morales by Frank Hayes after all. Bell said that the "decision to present that Hayes-Morales matter to a grand jury stemmed from his department's reconsideration of the dual prosecution guidelines," and from his view that the killing constituted a violation of Morales's federal civil rights. ${ }^{79}$ Prior to that policy change, state officials did not appreciate "federal meddling" and their federal counterparts respected their independence with a "hands-off policy on all but the most egregious civil rights abuses." With this change, Bell, along with President Carter, enabled "the Justice Department's Civil Rights Division to consider simultaneous prosecutions, regardless of state investigations." ${ }^{\circ 0}$

Ruben Sandoval, attorney for the Morales family, "said he was pleased with Bell's decision" but disgusted by the unwillingness of Texas officials to pursue justice. "I am concerned that we had to go all the way to Washington to get something done." ${ }^{81}$ In this instance the federal prosecutors won a major victory, convicting Hayes, his wife, and his sister-in-law for the violation of Morales's rights, and sending Hayes to prison for life, his wife to prison for three years, and his in-law to prison for eighteen months. Ruben Bonilla was not effusive about the results of the second prosecution but used them to excoriate the results of the first and to highlight the significance of the second. The outcome of this trial "was quite different from the San Angelo whitewash," ${ }^{82}$ he stated, but "the conviction in a civil rights case involving a Mexican American breaks new ground. Previous federal prosecution under the civil rights statutes had all involved blacks." 83

Mexican Americans certainly viewed the conviction of Hayes as an important precedent. Shortly thereafter, a visiting activist invoked the conviction in rallying Mexican Americans in Odessa to pursue justice in the killing of Larry Lozano. "I come with a message," he told an assembled group of six hundred. "Last Thursday in San Antonio in a case of similar nature to the Larry Lozano tragedy, Frank Hayes (former Castroville sheriff convicted of killing Richard Morales) was sentenced to life,'” the Odessa American reported. "That has never happened before. That is a message to all bigots who operate 'under the badge and pretext of law and order and violate our rights." 84

\footnotetext{
${ }^{79}$ Vickie Davidson, "Hayes Inquiry Sets Precedent," San Antonio Express, Feb. 12, 1977.

${ }^{80}$ Krajicek, "The Death of a Mexican-American at the Hands of a Texas Marshall in 1975 Triggered Civil Rights Action by Justice Department," New York Daily News, July 18, 2015.

${ }^{81}$ Davidson, "Hayes Inquiry Sets Precedent," San Antonio Express, Feb. 12, 1977.

${ }^{82}$ Krajicek, "The Death of a Mexican-American at the Hands of a Texas Marshall in 1975 Triggered Civil Rights Action by Justice Department," New York Daily News, July 18, 2015.

${ }^{83}$ Nick Jimenez, "Ex-Castroville Lawman Guilty: Life 'Appropriate,'” LULAC Journal (Galveston, Tex.), Sept. 5, 1977, Chicano Collection, UTRGV.

${ }^{84}$ Greg Watson, "Lozano Lawyer Says FBI Moving on Case," Odessa American, Feb. 20, 1978.
} 
In August 1978 Griffin Bell and Drew Days again made overtures toward Mexican Americans in Texas, underscoring the effectiveness of lobbying efforts by prominent Mexican American leaders and groups. "A top assistant to Attorney General Griffin Bell says new guidelines are being worked out to protect the rights of Mexican-Americans mistreated by law enforcement officers," reported the Longview Morning Journal. "His comments followed a verbal barrage by Mexican-Americans against the federal government's alleged sluggishness in prosecuting civil rights violations and cases of police brutality against Mexican Americans." The Journal specifically cited the efforts of Ruben Bonilla and Ruben Sandoval, noting that the latter, "a San Antonio lawyer, harshly criticized administration efforts in the civil rights area." 85

Despite the policy change and the notable victory in the Morales case, federal investigators and prosecutors still faced serious difficulties in their efforts to gain convictions against officers accused of offenses against Mexican Americans in the Lone Star State. Furthermore, they did not sustain their interest in such prosecutions, perhaps a reflection not only of a lukewarm commitment to this group but also of funding limitations, manpower constraints, workload priorities, and other issues. In the most dramatic indication of their disinterest, they allowed the five-year limitation contained in the civil rights statute to expire in 1978 without the prosecution of Officer Darrell Cain in the Santos Rodríguez killing. ${ }^{86}$ Furthermore, despite the policy changes, the Justice Department had few major victories after the highly qualified one in the Torres case and the more successful one in the Morales case.

After criticism from leaders like Bonilla, President Carter issued a statement acknowledging that "the outbreak of Mexican-American killing by police in Texas requires 'very strong, forceful' criminal action from the federal government" and asserting that "the Justice Department has responded adequately." After "virtual inactivity for years," acknowledged the LULAC Word, the Justice Department "has obtained criminal convictions of three former Houston police officers in the death of Joe Campos Torres and another against Castroville Sheriff Frank [Hayes] for the murder of Richard Morales-two of the most celebrated cases in Texas." ${ }^{87}$

Speaking in Washington, D.C., at the end of 1978, Mexican American leaders articulated what they saw as sloth masquerading as activism. "Asked whether Hispanics feel they are getting nothing more than "lip service' from the Justice Department," Eduardo Peña, the national presi-

\footnotetext{
85 "Justice Effort is Vowed," Longview Morning Journal, Aug. 1 2, 1978.

${ }^{86}$ Watson, "Police, the Mexican-American and Justice," Dallas Morning News, July 16, 1978.

87 "Carter Urges 'Very Strong' Action against Cop Killings of Hispanics," LULAC Word (Corpus Christi, Tex.), June 1978, Chicano Collection, UTRGV.
} 
dent of LULAC, responded: “It's worse than lip service. . . . We're being misled. What they're telling us is actually misleading.'" Pena indicated that civil rights leaders had been "having frequent meetings for months with high officials of the Justice Department, ranging up to Attorney General Griffin Bell. 'They have indicated-and sometimes I really believe them-that they are just about to do something tomorrow or the next day. They are very sympathetic and say they are determined to take action, to do something dramatic, and nothing happens.'” Another critic opined that the killings of Mexican Americans by officers, including "about 18 in Texas, 'seem to be lost in an interminable review process' within the department." In the meantime, Mexican Americans "believe they are being terrorized by the institutions that are charged with protecting them and keeping the peace." $" 88$

Even more difficult for federal officials were the police and their supporters. They responded to charges of violence and demands for reform not with self-reflection but with countercharges that resonated with many Anglos. They were effective, elevating the meritorious conduct of law enforcement personnel, stoking Anglo fears, and blaming minoritiesoften in couched terms-for their victimization. Some of their leaders dismissed the suggestion that any statistically significant number of officers subscribed to racist attitudes or displayed these at work. "A police chief [in] a mostly white Dallas suburb" told the Dallas Morning News that charges of violence were a means of smearing good officers. "The FBI investigates the incident, and you're run through the wringer, and it all turns out most of the time that the poor old police was telling the truth, and the complaint was unfounded.' "In vouching for his men and the burden they carried, he implied that they might not endure such abuse forever. "He didn't think law enforcement officers would be intimidated by what he termed as distorted and false, accusations that the Chicano civil rights push is [pressing]." He added: “'If it continues, it's going to come to the point where the police are going to start screaming and yelling civil rights themselves. They're citizens too, and where can you show me that a police officer has to put up with abuse and assault?'" 89

Other leaders played on the growing fears of their majority constituents. Lloyd Mathews, the president of the Texas Police Officers Association, was one. "'In the last few months, we've become the target, and once an unfounded story is told, you can't erase it. ... Will we see more officers killed in the line of duty for hesitating too long in that split second?'”

\footnotetext{
88 "U.S. 'Misleading' Hispanics in Pretense to Prosecute Police Cases," LULAC Word (Corpus Christi, Tex.), December 1978, Chicano Collection, UTRGV. See also Watson, "Police, the Mexican-American and Justice," Dallas Morning News, July 16, 1978; Grove, "Police Brutality Not Seen as Problem," Dallas Morning News, June 3, 1978.

${ }^{89}$ Watson, "Police, the Mexican-American and Justice," Dallas Morning News, July 16, 1978.
} 
Sheriff Culbertson predicted that any reform of police practices would constitute a nightmare for law-abiding residents. He stated that he "had a personal fear" that, if officers continued to face criticism, they "might realistically begin thinking, 'They see a Mexican-American commit a crime, let's leave him alone."'90

Still others argued that the tensions between police and minority communities resulted not from the racism of officers but from the criminal proclivities of minorities. "Kenneth J. Mighell, U.S. attorney for the Northern District of Texas, said there may be more complaints of police brutality filed by Mexican-Americans and blacks than by Anglos, but that is because more minorities" broke more laws. "There seems to be a general feeling that Mexican-Americans are somehow put upon in this state, and I frankly do not agree with that," he declared. "It's just that on a percentage basis, a lot more Mexican-Americans and blacks are normally in the custody of the police. Therefore, police brutality cases would be more in the minority area." "91 The police and their supporters were so effective in making their case to the majority that minority critics felt compelled to address them by acknowledging that abusive officers constituted but a tiny minority. Froy Salinas, for instance, declared that "he believes that 98 percent or more of the peace officers in Texas are 'good solid folks." "992

By the end of 1978 many Mexican Americans had come to regard that year as an annus horribilis. In its last issue of the year the LULAC Word concluded that police violence was the single most important civil rights issue in the state and asserted that Mexican Americans were suffering as a result from "a loss of confidence and the setting in of frustration and bitterness." In its retrospective the Word described 1978 as "one of the most turbulent and most traumatic years in recent Mexican-American history" and characterized it as "a remarkable year, not for what we accomplished, but largely because of the boldness of the full fledged assault on the standard and quality of life for the majority of Mexican Americans across Texas. I hope we can work together in 1979 to avoid further pitfalls. ${ }^{\prime 93}$ Ironically, Mexican Americans may have fallen victim to their own remarkably successful publicity campaign against police violence. After all, given the rash of killings in Austin in the early 1970s, it is not clear that police officers killed more Mexican Americans under suspicious circumstances in 197778 than in other years, but it is clear that Mexican Americans, Anglos, and police officers around the state experienced the killings in that period as a dramatic and even unprecedented surge.

\footnotetext{
${ }^{90}$ Ibid.

${ }^{91}$ Grove, "Police Brutality Not Seen as Problem," Dallas Morning News, June 3, 1978.

${ }^{92}$ Watson, "Police, the Mexican-American and Justice," Dallas Morning News, July 16, 1978.

93 "Director's Insight," LULAC Word (Corpus Christi, Tex.), December 1978, Chicano Collection, UTRGV.
} 
The Dallas Morning News affirmed this perception of a spike in July of 1978. "In the past 18 months [the] historic distrust of law enforcement officials by Hispanics in Texas and the southwest in general has surfaced as a common bond and created a cause that one out of six Texans can closely identify with when someone points a brown finger at a badge and makes accusations about injustice and brutality or murder while a Chicano is in police custody." ${ }^{4}$ Texans' perception, however, may not have squared with reality. While the evidence is not conclusive, Mexican American protesters may in fact have created a powerful but incorrect perception of a spike in killings because of the unusual levels of media attention and public discourse which their actions attracted.

Furthermore, state and national (largely Anglo) political leaders, motivated by factors like Mexican American activism, demographic changes, and attendant electoral implications, did respond-grudgingly perhapsto some of the concerns expressed by this minority. By altering federal policy toward dual state and federal investigations into incidents of police violence and then by prosecuting and convicting Frank Hayes of Castroville, U.S. Attorney General Bell showed his willingness, and that of President Carter, to act on their concerns. However, aside from the shift in policy itself (a shift that would be only as significant as those enforcing the laws chose to make it) and the triumph in Castroville, Bell did little more than make symbolic gestures.

Certainly, this study expands on the growing literature on racist mob violence against persons of Mexican descent in Texas by examining in a more comprehensive fashion police violence by local law-enforcement forces against Mexican Americans in the 1970s. The evidence suggests that racist violence generally and police violence specifically provides fertile ground for study. Mexican Americans from all economic classes and ideological persuasions participated in the Mexican American civil rights struggle, although they subscribed to an array of ideologies, strategies, and tactics. Older, more economically established Mexican Americans tended to pursue change institutionally through organizations like LULAC that applied pressure on politicians eager to maintain their hold on power and cognizant of the growing impact of demographic changes within the Mexican American community. Younger, often more working-class Mexican Americans, attracted to the vision of the Chicano Movement, aired their grievances, demanded the arrest and prosecution of offending officers, and pressed for structural transformation in the administration of the law. Both groups flourished during the violence of 1977-1978, raising questions about the conclusions of those who assert that "by the late 1970 s the Chicano movement was a phenomenon of the past." ${ }^{\prime 95}$

\footnotetext{
${ }^{94}$ Watson, "Police, the Mexican-American and Justice," Dallas Morning News, July 16, 1978.

${ }^{95}$ Ernesto Chávez, Mi Raza Primero!: Nationalism, Identity, and Insurgency in the Chicano Movement in Los
} 
This study further challenges those scholars who, like Ernesto Chávez, argued that, "as ethnic Mexicans returned [in the late 1970s] to smaller efforts like those of the 1950s," the large-scale protests "of the previous decade gave way in the 1980 os to smaller efforts focused on electoral politics." Chávez called this "the turn toward mainstream electoral politics," a turn which, he said, "brought complacency." ${ }^{" 96}$ With its focus on the efforts of more conservative Mexican American leaders like Bonilla, Salinas, and García, this study suggests that this "turn" was more a continuation of the strategy pursued by these leaders unabated from the end of World War II into the 1980 os. In fact, it shows that this protest strategy, sometimes overlooked by scholars concerned with the more "radical" Chicanos, was persistent, unyielding, and to an extent successful. It also shows that this strategy, supplemented by rallies, produced the change in federal policy by Bell, sent a message to police through a handful of qualified courtroom victories, and used demographic shifts in the populace as a prod to persuade Anglo politicians to take Mexican American concerns seriously.

The inclusion of incidents of police violence less familiar than the higher-profile incidents addressed by scholars like David Montejano, Brian Behnken, and Ernesto B. Vigil serves two purposes. ${ }^{97}$ The inclusion of obscure incidents in Big Spring, Waco, and Sierra Blanca with wellknown incidents like the killings in Dallas, Castroville, and Houston provides a compelling narrative that testifies to the number of incidents in the state during the mid-1970s, identifies patterns of police misconduct, and describes the breadth of community responses to such misconduct. Furthermore, the addition of these less familiar incidents attests to the need for the comprehensive tabulation of the police killings of persons of Mexican descent across the Southwest and the evaluation of the similarities and differences in the frequency, motivations, and consequences of these events over time and space, just as scholars have investigated the lynchings of Mexican Americans and African Americans in the nineteenth and early twentieth century. Such an effort would probably challenge and reconfigure a host of scholarly assumptions made in those previous investigations.

Although this study focuses on police violence against Mexican Americans in Texas in the 1970 s, it does suggest the possibility of similar patterns in other southwestern states and underscores the need for more comprehensive research directed at those states. Certainly the available evidence corroborates this assertion. In 1978 a Mexican American activist

\footnotetext{
Angeles, 1966-1978 (Berkeley: University of California Press, 2002), 118-1 19. For similar interpretations, see Montejano, Anglos and Mexicans, 289; Juan Gómez-Quiñones and Irene Vásquez, Making Aztlán: Ideology and Culture of the Chicana and Chicano Movement, 1966-1977 (Albuquerque: University of New Mexico Press, 2014).

${ }^{96}$ Chávez, Mi Raza Primero!, 119.

${ }^{97}$ In addition to the works of Montejano and Behnken, see Ernesto B. Vigil, The Crusade for Justice: Chicano Militancy and the Government's War on Dissent (Madison: University of Wisconsin Press, 1999).
} 
confirmed that "police brutality against Chicanos, always a problem, has become worse during the last two years. As proof she notes that 16 Chicanos were either beaten or shot to death by policemen during that period in California, Texas, New Mexico and Colorado alone." 98

With its focus on the shift in federal policy in the Justice Department after the Castroville killing, this study contributes to the historiography of the overlapping and intertwined civil rights struggles. It shows, for instance, that developments with respect to Mexican Americans had profound implications for African Americans. In a recent retrospective on the Castroville killing, the New York Daily News remarked that, "In effect, Bell and Carter had changed federal policy, enabling the Justice Department's Civil Rights Division to consider simultaneous prosecutions, regardless of state investigations." Significantly, it added that this altered relationship remains "intact today and has been used in a number of recent controversial deaths involving police, including cases in Ferguson, Mo., Staten Island, Baltimore and North Charleston, S.C." ${ }^{\prime 9}$ This suggests the need, even as scholars trace the particulars of the African American, Mexican American, Asian American, and other racial and ethnic rights struggles, to synthesize these stories where appropriate and to underscore that none of them occurred in a vacuum. ${ }^{100}$

Police violence against minority populations seems to have a way of falling out of public memory, and the killings of Mexican Americans and Mexican nationals by officers in Texas in the 1970s are no exception. However, the response to them by groups and individuals throughout the Mexican American community in Texas forced the federal government to take notice. Minority communities throughout the country have followed their example in calling on federal resources to address grievances against local police; whether this has led to justice for the bereaved, though, remains an open question.

\footnotetext{
${ }^{98}$ David Reyes, "Head of Mexican-American Defense-Education Believes Police Brutality with Chicanos Increasing," Statesman Journal (Salem, Ore.), July 2, 1978.

${ }^{99}$ Krajicek, "The Death of a Mexican-American at the Hands of a Texas Marshall in 1975 Triggered Civil Rights Action by Justice Department," New York Daily News, July 18, 2015.

${ }^{100}$ On racist violence by Anglos against blacks, ethnic Chinese, and ethnic Italians in the U.S. West, see Brent M. S. Campney, This Is Not Dixie: Racist Violence in Kansas, I86I-I927 (Urbana: University of Illinois Press, 2015); Jean Pfaelzer, Driven Out: The Forgotten War against Chinese Americans (New York: Random House, 2007); Gonzales-Day, Lynching in the West; Leonard, Lynching in Colorado.
} 